\title{
Development of Near Isogenic Lines of Wheat Carrying Different Spike Branching Genes and Their Agronomic and Spike Characters
}

\author{
Weidong Zhang ${ }^{1}$, Anfei $\mathrm{Li}^{1}$, Jichun Tian ${ }^{1,2}$, Lanfei Zhao ${ }^{2}$ \\ ${ }^{1}$ Agronomy College, State Key Laboratory of Crop Biology, Shandong Agricultural University, China \\ ${ }^{2}$ Sub-Center of Cereal Quality Control and Test (Taian), Ministry of Agriculture of China, China \\ Correspondence: Jichun Tian, Agronomy College, Shandong Agricultural University, Taian 271018, Shandong, \\ China. Tel: 86-538-8248196. E-mail: jctian1954@yahoo.com.cn
}

Received: April 4, 2012 Accepted: April 23, 2012 Online Published: July 11, 2012

doi:10.5539/jas.v4n8p215 URL: http://dx.doi.org/10.5539/jas.v4n8p215

\begin{abstract}
The branched spike introduced from T. turgidum in common wheat was controlled by two recessive genes ( $s b 1$ and $s b 2$ ). The effect of specific $s b$ on the development and spike characters can be accurately determined by using isogenic lines (NILs), which, however, were not usually available. In this study, four genotypes having different combinations of the two $s b$ genes with a common genetic background $c v$. Taishan were produced by continuous backcrossing and determined by crossing and test-crossing. The four NILs included one line with branched spike, DR ( $s b 1 s b 1 s b 2 s b 2)$, and three lines with normal spike, SR1 (sb1sb1 Sb2Sb2), SR2 (Sb1Sb1 $s b 2 s b 2)$, and DD (Sb1Sb1 Sb2Sb2). These NILs were grown during two growing seasons (2008-2009 and 2009-2010) to investigate the effects of $s b$ genes on agronomic and spike characters. The results showed that SR1 postponed significantly the days to heading and the days to anthesis, and SR2 decreased significantly grain number by reducing the fertile floret in a spike. DR not only displayed the branched spike but also had great effects on agronomic and spike characters. In DR, the days to maturate was significantly postponed, and the number of fertile floret and grain number increased in a spike, but the grain set reduced significantly. This indicated the $s b$ combinations have different effects on the agronomic and spike characters. This research made foundation for analyses of mechanisms of branched spike formation and associated properties in hexaploid wheat in future.
\end{abstract}

Keywords: branched spike wheat, spike branching gene $(s b)$, near isogenic lines (NILs), development stage, spike

\section{Introduction}

The main components of wheat yield are the spike number per unit land area, the number of grains per spike, and the average weight of those grains. Branched spike Wheat (BSW) (Triticum aestivum) has a main rachis as normal common wheat, but it bears extended branched rachides at main rachis node. Spikelets are borne on branched rachides and thus a branched spike might offer more possibility for spikelet than a normal spike. This kind of wheat has potential to increase greatly the productivity of the crop (Koric, 1969; Li et al., 2000).

So far, two types of branched spike have been reported: turgidum (regular) and vavilovii (irregular). The first one is specific for spike of T. turgidum L., and this type of branching was also called supernumerary spikelet (Coffman, 1924; Peng et al., 2004; Aliyeva et al., 2011).

The branching characters of this spike was incorporated into T. aestivum using wide crosses between T. aestivum and branching forms of T. turgidum (Koric, 1980; Dencic, 1988; Huang et al., 1988.).

The genetics of this branched spike character in wheat has been studies for over ninety years. In T. turgidum, this character was found to be inherited in a recessive manner (Tschermak, 1914; Sharman, 1967). The inheritance of the spike branching $(s b)$ in common wheat was found to be controlled by two recessive genes with cross experiments between normal spike and branched spike lines (Koric, 1980).

This supernumerary spikelet character in this type of spike was also affected by light, temperature, nutrients and environmental conditions (Koric, 1975; Peanel1, 1983), and environmental factors played a minor effect on the character expression during spike differentiation stage at the same eco-region (Sun et al., 2000). 
About twenty years ago (1993), Fen33, a BSW cultivar with the spike of T. turgidum was released in some northern western China wheat zones. It was selected from interspecies hybridization of T. turgidum $\times$ T. aestivum. Its branched spike character was derived from T. turgidum, and stability of branched spike character of Fen33 was similar with T. turgidum in different cultivate environments (Yuan et al, 1995). The branched spike character in Fen33 was controlled by two recessive genes and affected by some modifying genes (Zhao et al, 2009).

It had been demonstrated that the two spike branching genes $(s b)$ in Fen33 were located at $2 \mathrm{~A}$ and 2D chromosome respectively (Yan et al., 2007). One was located between SSR markers gwm372 and wmc502 on 2A, and another was located between SSR markers gwm484 and gwm102.

However, very little research has been focused on effects of different $s b$ combinations on the agronomic traits in hexaploid wheat, and this could be due to the lack of suitable materials. The present study was conducted with the aims of producing four possible genotypes of NILs having different $s b$ combinations and characterizing initially their field performances and main spike properties. These results might be helpful for further accurate analyses of mechanisms on branched spike formation and associated agronomic properties.

\section{Materials and Methods}

\subsection{Materials}

Fen33 as non recurrent parent and $s b$ genes donor, and Taishan as recurrent parent were used in construction of backcross populations. In China, Fen33 with branched spike was released in Northwestern wheat zone in 1993, and Taishan with normal spike was an elite cultivar from Huanghuai Wheat zone.

Four NILs with different $s b$ gene combinations from a BC population were used in agronomy and spike investigation. These NILs included that DR (double recessive, $s b 1 s b 1 s b 2 s b 2)$ with branched spike and DD (double dominant, $S b 1 S b 1 S b 2 S b 2$ ), SR1 (single recessive 1, Sb1Sb1 sb2sb2) and SR2 (single recessive 2, sb1sb1 Sb2Sb2) with normal spike. Fen33 and Taishan were also grown as check in the fields.

All experiments were conducted at the Experimental Farm for Cereal Research in Agronomy College of Taian, and Shandong Agricultural University. The development of NILs began from 1996 and the agronomic and spike characters of the NILs were investigated during two growing seasons (2008-2009 and 2009-2010).

\subsection{Development of NILs Carrying Different sb Combinations}

The NILs were developed as early as 1996. The NILs development route in our research roughly included 3 steps: (1) Obtaining $\mathrm{BC}$ populations by successive backcrosses and $\mathrm{DR}$ lines were determined in the $\mathrm{BC}_{6} \mathrm{~F}_{4}$ population; (2) Obtaining SR1, SR2 and DD lines by crosses among $\mathrm{BC}_{6} \mathrm{~F}_{4}$ lines within normal spike in diallel hybridization; (3) Determining unambiguously SR1, SR2 and DD by test crossing with DR lines. However, in our practical operations, many crosses in step 2 and step 3 were performed at mean time. In the $\mathrm{BC}_{6} \mathrm{~F}_{4}$ population, lines with normal spike diallel-crossed and they were test-crossed with DR to determinate their genotypes. The normal spike lines with different $s b$ combinations were obtained in $\mathrm{BC}_{6} \mathrm{~F}_{5}$ to $\mathrm{BC}_{6} \mathrm{~F}_{8}$ populations. This development procedure increased greatly workload but speed up the development of the set of NILs.

\subsection{Agronomic and Spike Characters Experiments}

In 2008, sufficient seeds of the four NILs were available for a field test at one location. The test was a randomized complete block design (RCBD) with four replications of four-row plots. The plots were $2.50 \mathrm{~m}$ long with $30.5 \mathrm{~cm}$ between rows and plots. In all experiments, plots were irrigated to complement natural rainfall during the whole growing season to avoid water stress. Urea was applied both at sowing $\left(50 \mathrm{~kg} \mathrm{~N} \mathrm{ha}^{-1}\right)$ and at tillering $\left(30 \mathrm{~kg} \mathrm{~N} \mathrm{ha}^{-1}\right)$. Fungicides and insecticides were sprayed to prevent diseases and insect damage, and weeds were manually removed throughout the growing season.

From seedling emergence to maturity, experimental units were monitored regularly to determine the timing of terminal heading, anthesis and maturity (Zadoks et al., 1974). The timing of heading, anthesis and maturity were visually determined when $50 \%$ plants per experimental unit had reached these stages. Plant height from the soil surface to the base of the spike was measured on five main shoots per experimental unit at maturity.

The number of fertile florets in main shoot spikes was determined at anthesis and the numerical yield components of grains per spike and spikelets per spike were determined at maturity. A floret was considered to be fertile when male and female reproductive organs had developed green anthers and bifidum stigma, respectively (Waddington et al., 1983). Grain set was the proportion of fertile florets setting a grain in main shoot spikes. The entire mature spike in each spot was harvested by hand and the yields were measured. The seed of all four replicates for each entry were weighted per 1000 kernels. 


\subsection{Statistic al Analysis}

All experimental data were subjected to analysis of variance (ANOVA) using SPSS, version 19.0 (SPSS, 2010). Mean values were compared by the LSD method or Duncan's multiple range test at the $5 \%$ level.

\section{Results and Discussion}

\subsection{Development of NILs Carrying Different sb Combinations}

A set of NILs with Taishan as the recurrent parent were obtained and the general produce process was shown in Figure 1.

Branched spike wheat lines fen33 was crossed with normal spike wheat $c v$. Taishan. In a $\mathrm{BC}_{6} \mathrm{~F}_{2}$ population from one $\mathrm{BC}_{6} \mathrm{~F}_{1}$ plant, 18 lines with branched spike appeared and all the 302 lines were assigned serial numbers. The corresponding $\mathrm{BC}_{6} \mathrm{~F}_{4}$ lines were obtained by a single seed descent. All these lines could be regarded as NILs. In the $\mathrm{BC}_{6} \mathrm{~F}_{4}$ population, 75 lines had branched spike, and they were $\mathrm{DR}$ plants. In the $\mathrm{BC}_{6} \mathrm{~F}_{4}$ population, 12 lines with normal spike crossed in incomplete diallel design and test-crossed with one DR line at mean time. The following $F_{2}$ and $F_{t}$ plants were planted in respective bulk plot for each cross. Following the progeny's segregation rate, a set of NILs with normal spike carrying different $s b$ genes were obtained unambiguously. They included 2 lines of SR1, 3 lines of SR2, and 2 lines of DD. One line from each genotype group was selected as experiments' materials in following field researches.

Branched spike is the main selection criterion in this research. However, branched rachides length varied greatly in $\mathrm{BC}$ populations. The lengths of branched rachides in some lines were very short, and it seemed that several "florets" were clustered together. Based on pairs of lemma, it could be seen that they were spikelets, not florets, attached at a branched rachis node. In these selections, this kind of branched spikes could be included in statistics, but they would not be used for backcrosses with recurrent parents.

Generally, it is difficult to construct a BC population with a character controlled by multiple genes, especially when the control genes are recessive genes. In order to accelerate the construction of $\mathrm{BC}$ populations, backcross and self cross were conducted simultaneously in $\mathrm{BC}_{n} \mathrm{~F}_{1}$ generation, and the spike phenotypes in $\mathrm{BC}_{\mathrm{n}} \mathrm{F}_{2}$ determined if the $\mathrm{BC}_{\mathrm{n}+1} \mathrm{~F}_{1}$ could be used for next backcross. In this research, no less than 10 spikes from different $\mathrm{BC}_{\mathrm{n}} \mathrm{F}_{1}$ lines were selected for backcross and self cross. The spikes in a line were divided into 2 samples, one sample (2-3 spikes) was backcrossed with the recurrent parent to obtain $\mathrm{BC}_{\mathrm{n}+1} \mathrm{~F}_{1}$ and the second sample was selfcrossed to obtain $\mathrm{BC}_{n} \mathrm{~F}_{2}$. The $\mathrm{BC}_{\mathrm{n}+1} \mathrm{~F}_{1}$ and $\mathrm{BC}_{\mathrm{n}} \mathrm{F}_{2}$ populations from the same line were planted in the field simultaneously. If wheat lines with branched spike existed in a $\mathrm{BC}_{\mathrm{n}} \mathrm{F}_{2}$ population, the corresponding original $\mathrm{BC}_{\mathrm{n}} \mathrm{F}_{1}$ plants might be heterozygous at the both $s b$ gene loci. The corresponding $\mathrm{BC}_{\mathrm{n}+1} \mathrm{~F}_{1}$ line might also have possibility to be heterozygous at both $s b$ loci and the plants from this population could be used for subsequent backcross. Otherwise, if no branched spike lines were found in $\mathrm{BC}_{\mathrm{n}} \mathrm{F}_{2}$, the corresponding $\mathrm{BC}_{\mathrm{n}} \mathrm{F}_{1}$ plants might be heterozygous at only one $s b$ locus or homozygous with no $s b$ genes at both loci. Its corresponding $\mathrm{BC}_{\mathrm{n}+1} \mathrm{~F}_{1}$ plants were discarded and not used for next backcross.

Conventional methods were used in the development of NILs in this research, including successive backcrosses and phenotypic identification in each $\mathrm{BC}$ generation. Tedious work in the field was necessary in this process. At present time, the development of molecular mark assisted selection has becoming a useful tool in recessive gene-controlling phenotype identification, such as in common wheat (Samsampour et al., 2010), leaf mustard (Yan et al., 2009), and soybean (Seversike et al., 2008). Molecular efficient linkage marker should be useful for identifying the normal spike lines with $s b$ genes. At the later time of the NIL development, Yan (2007) reported that the $s b$ genes were respectively linked to SSR markers on 2A chromosome and 2D chromosome, and the nearest genetic distances was $9 \mathrm{cM}$ between SSR marker gwm372 and a $s b$ gene on $2 \mathrm{~A}$ chromosome. However, they could not be efficiently used in our selection of NILs with $s b$ genes. This could be due to genetic recombination between $s b$ genes and SSR markers during the NILs development.

\subsection{Agronomic Characters of the NILs Carrying Different sb Combinations}

The entries were planted in the field and the agronomic data were shown in Table 1. After successive backcrosses, the four NILs were no significant differences in plant height in either year $(\mathrm{P}>0.05)$. The development stages of the four NILs with different $s b$ combinations were very similar one another, but they had their respective characteristics.

Among the four NILs, in the days to heading, the four NILs comprised between 190.2-192.8 days and 181.3-183.8 days in 2009 and 2010 respectively. SR1 was significantly different with DD $(\mathrm{P}<0.01)$ in the two growing seasons, and it was after 2.6 days and 2.5 days off in 2009 and 2010 respectively. In days to anthesis, SR1 was after 2.2 days and 1.7 days off in 2009 and 2010 respectively compared with DD. The duration of SR2 
was longer in the days to heading, shorter in the days to anthesis than $\mathrm{DD}$, but none of these differences reached the significant levels $(\mathrm{P}>0.05)$. This might indicate that $s b 1$ and $s b 2$ had different influences on the days to heading and the days to anthesis. DR was also longer than DD and SR2 in the days to heading and the days to anthesis. For the days to maturate, DR was significantly longer than any other three near-isogenic counterparts $(\mathrm{P}<0.01)$, but there were no significant differences among the other three NIls $(\mathrm{P}>0.05)$.

Table 1. Development stage characteristics of the four near-isogenic lines grown at Taian in 2008 and 2009

\begin{tabular}{lllllllll}
\hline & \multicolumn{2}{l}{ Days to heading } & \multicolumn{2}{l}{ Days to flower } & \multicolumn{2}{l}{ Days to maturity } & \multicolumn{2}{l}{ Plant height $(\mathrm{cm})$} \\
\hline & $2008-2009$ & $2009-2010$ & $2008-2009$ & $2009-2010$ & $2008-2009$ & $2009-2010$ & $2008-2009$ & $2009-2010$ \\
\hline DD & $190.2 \mathrm{c}$ & $181.3 \mathrm{~b}$ & $196.2 \mathrm{~b}$ & $186.6 \mathrm{~b}$ & $230 \mathrm{bc}$ & $224.9 \mathrm{a}$ & $75 \mathrm{~b}$ & $71.9 \mathrm{~b}$ \\
$\mathrm{SR} 1$ & $192.8 \mathrm{a}$ & $183.8 \mathrm{a}$ & $198.4 \mathrm{a}$ & $188.3 \mathrm{a}$ & $231.5 \mathrm{~b}$ & $223.5 \mathrm{~b}$ & $76.9 \mathrm{a}$ & $73.6 \mathrm{a}$ \\
SR2 & $191.1 \mathrm{~b}$ & $182.4 \mathrm{ab}$ & $195.8 \mathrm{~b}$ & $185.7 \mathrm{c}$ & $229.4 \mathrm{c}$ & $224.8 \mathrm{a}$ & $72.8 \mathrm{c}$ & $68.4 \mathrm{c}$ \\
DR & $192.3 \mathrm{a}$ & $183.7 \mathrm{a}$ & $198.5 \mathrm{a}$ & $188.4 \mathrm{a}$ & $232.9 \mathrm{a}$ & $225.6 \mathrm{~b}$ & $74.6 \mathrm{bc}$ & $69.8 \mathrm{c}$ \\
& & & & & & & & \\
Fen 33 & 196.5 & 186.4 & 205.9 & 194.6 & 238.4 & 231.6 & 65.3 & 63.5 \\
Taishan & 189.3 & 179.5 & 196.6 & 187.3 & 228.7 & 222.6 & 74.3 & 75.3 \\
\hline
\end{tabular}

The duration of the development stages depends on genotype and environment. Different genotypes have different photoperiod sensitivity, vernalisation properties which regulating the time from sowing to anthesis (Flood et al., 1984). Many tillage methods, such as crop rotation (Verhulst et al., 2011), early sowing (Gbmez-Macpherson et al., 1997), plant growth regulators (Biesaga-Koscielniak et al., 2010), and fertilizer (Oscarson et al., 1995) also had effects on the development stages. Some genes and QTLs related with development stages have been obtained in wheat. Three major genes in wheat vernalisation pathway have been cloned: VRN1 (Yan et al. 2003), VRN2 (Yan et al. 2004), and VRN3 (Yan et al. 2006), and they had effects of the reproductive development in wheat. Chen et al. (2010) reported that three major QTLs were found to control variation in developmental process, and each of them was tightly associated with a known flowering gene. The roles of $s b 1$ or $s b 2$ on reproductive development stages deserve further research.

In addition, it was not surprised that the four NILs were near to Taishan, and significantly different with Fen33 on the development stages. Fen33 was significantly later than Taishan in all the investigated development stages. Among the investigated developmental stages, the days to heading for fen33 in 2009 test was most close to that of Taishan, and it was later for 6.9 days. The differences could be due to their original cultivation zones. Fen33 was planted in Northwestern wheat zone in China, and Taishan was suitable to be cultivated in Huanghuai wheat zone, although both of them were winter wheat.

\subsection{Spike Characters of NILs Carrying Different sb Combinations}

The six entries in this experiment could be divided into two categories by their spike types, namely normal spike and branched spike. SR1, SR2, DD and Taishan had normal spike, and DR and fen33 had branched spike. The results of spike characters of the entries were shown in Table 2.

Table 2. Spike characters of the four near-isogenic lines grown at Taian in 2008 and 2009.

\begin{tabular}{|c|c|c|c|c|c|c|c|c|c|c|}
\hline & \multicolumn{2}{|c|}{ Grains per spike } & \multicolumn{2}{|c|}{ Spikelets per spike } & \multicolumn{2}{|c|}{ Fertile florets per spike } & \multicolumn{2}{|c|}{ Grain set $(\%)$} & \multicolumn{2}{|l|}{ Weigh/1000 } \\
\hline & 2009-2010 & $2010-2011$ & $2009-2010$ & 2010-2011 & $2009-2010$ & $2010-2011$ & $2009-2010$ & $2010-2011$ & $2009-2010$ & 2010-2011 \\
\hline DD & $45.5 \mathrm{~b}$ & $48.6 \mathrm{~b}$ & $17.3 \mathrm{~b}$ & $16.8 \mathrm{~b}$ & $57.6 \mathrm{~b}$ & $64.3 \mathrm{~b}$ & $79.0 \mathrm{~b}$ & $75.6 \mathrm{a}$ & $38.0 \mathrm{~b}$ & $40.5 b$ \\
\hline SR1 & $44.7 \mathrm{~b}$ & $46.2 \mathrm{bc}$ & $15.6 \mathrm{c}$ & $16.5 \mathrm{bc}$ & $56.5 \mathrm{~b}$ & $65.2 \mathrm{~b}$ & $83.1 \mathrm{a}$ & $77.9 \mathrm{a}$ & $39.2 \mathrm{~b}$ & $42.1 \mathrm{a}$ \\
\hline SR2 & $41.1 \mathrm{c}$ & $43.5 \mathrm{c}$ & $16.4 \mathrm{bc}$ & $15.6 \mathrm{c}$ & $53.8 \mathrm{bc}$ & $59.3 \mathrm{c}$ & $72.7 \mathrm{c}$ & $66.7 \mathrm{c}$ & $41.3 \mathrm{a}$ & $41.2 \mathrm{ab}$ \\
\hline DR & $68.6 \mathrm{a}$ & $73.5 \mathrm{a}$ & $32.1 \mathrm{a}$ & $34.9 \mathrm{a}$ & 98.9 a & $102.3 \mathrm{a}$ & $69.3 \mathrm{c}$ & $71.8 \mathrm{~b}$ & $29.7 \mathrm{c}$ & $32.5 \mathrm{c}$ \\
\hline Fen 33 & 74.5 & 81.3 & 35.6 & 38.9 & 113.5 & 121.6 & 65.7 & 66.9 & 26.9 & 31.3 \\
\hline Taishan & 47.2 & 49.2 & 18.9 & 17.6 & 62.4 & 68.9 & 75.6 & 71.4 & 40.3 & 41.3 \\
\hline
\end{tabular}

Among the four NILs, the spikes of DD, SR1 and SR2 looked very similar and to that of Taishan, except that Taishan had a slightly more compact head. In two growing seasons, the grain number of SR1 and SR2 reduced significantly compared with DD $(\mathrm{P}<0.05)$. SR2 reduced much more than SR1. Compared with DR, the grain number per spike in SR2 was decreased by $9.84 \%$ and $11.03 \%$ in 2009 and 2010 respectively, and that in SR1 
decreased only by $1.75 \%$ and $4.93 \%$ in corresponding year. The reduction in grain number per spike might be due to the decrease in fertile floret. Compared with DD, the number of fertile floret in SR2 reduced significantly $(\mathrm{P}<0.01)$ in both growing years, ant they were decreased by $6.72 \%$ and $7.67 \%$ in 2009 and 2010 respectively. However, the number of fertile floret in SR1 did not change markedly. In 2009 growing year, SR1 increased by $1.40 \%$ in fertile floret.

In grain weight, a single degree of freedom comparison between DD and SR1 and SR2 as a group was significant in $2010(\mathrm{P}<0.05)$ but not significant in $2009(\mathrm{P}>0.05)$. There were no significant differences between $\mathrm{SR} 1$ and SR2 $(\mathrm{P}>0.05)$ in both growing years. The grain weight in SR1 and SR2 was slightly higher than that of DD. It seemed that $s b 1$ or $s b 2$ might have no detrimental effects on the grain weight. That indicated that the lower grain weight of DR could not be due to the role of $s b 1$ or $s b 2$, could be due to the interaction of $s b 1$ and $s b 2$, which resulted in the branched spike and more grains in a spike. Poor grain weight in branched spike might be resulted from other factors, such as little nutrition, or compact of grain in a spike during development.

DR had distinctly different spike type with other near-isogenic counterparts. DR was significantly different with them in all the investigated spike characters. Compared with all the three normal spike NILs, it had significantly higher grain number, spikelet and fertile floweret, but lower grain set and grain weight $(\mathrm{P}<0.01)$ (Table 2).

Grain yield per plant in DR was significantly higher than that in DD, the grain yield increased $6.45 \%$ and $2.69 \%$ in 2008 and 2009 respectively. The grain yields in DR were not stable between the two growing years. In past research, it had been demonstrated that the spike morphological characters in branched spike wheat were easily affected by environmental factors, and this was one of the main causes restricting its wide application. Grain yield per plant in SR1 and SR2 was significantly lower than that in DD $(\mathrm{P}<0.01)$. This was because that SR1 and SR2 had lower spike number per plant.

DR has common traits with fen33 in spike characters. Compared with normal spike lines, they had higher grain number, spikelet and fertile floweret, but lower grain set and grain weight (Table 2). There were significant differences in these four spike characters between DR and Fen33. The grains, spikelets and fertile florets per spike in DR were significantly reduced compared with those in Fen33 $(\mathrm{P}<0.01)$, this could be due to the number of branching rachides was reduced in DR. The spike morphology changes greatly in branched spike wheat, especially the number and length of branched rachides. In order to efficiently use this kind of new spike type wheat, wheat lines with more coordinate spike components should be selected in breeding program.

Wheat spike characters could be affected by many factors. Extensive research had early been focused on the grain number, fertile floret number, spikelet number, grain set and grain weight in normal spike wheat. For the set of NILs in this research, $s b 2$ seemed to have great effects on the fertile floret number. It has been reported that the number of fertile florets in wheat was affected by photoperiod sensitivity genes $P p d-D 1$ and $P p d-B 1$ in pre-anthesis development (Gonzalez1 et al., 2005) and then it could affected other grain characters. Although $s b 1$ also had impacts on some spike characters, it had fewer impacts than $s b 2$ on the fertile floret number. Up to now, many genes involving spike characters have been determined in wheat. Two putative cytokinin oxidase genes were reported to be related to grain number per spike in wheat (Zhang et al., 2011), An earliness per se locus Eps-Aml affecting spikelet number in diploid wheat had been located on the distal region of $T$. monococcum chromosome $1 \mathrm{~A}^{\mathrm{m}} \mathrm{L}$ (Lewis et al., 2008). In addition, the new type of spike morphology, branched spike, was produced from the interaction of $s b 1$ and $s b 2$. This kind of branched inflorescence generally was produced from ectopic SAM (shoot apical meristem) (Danilevskaya et al., 2010), and $s b 1$ and $s b 2$ might be synergistically involved in the formation of ectopic SAM in wheat young spike. The distinct roles of $s b 1$ or $s b 2$ and their combined roles also deserve to be studied more deeply.

\section{Conclusion}

This research showed that both $s b 1$ and $s b 2$ have effects of agronomic and spike characters. $s b 1$ has greater influences on the days to heading and days to anthesis and $s b 2$ has fewer influences on these two development stages. $s b 2$ decreased grain number in a spike by reducing the fertile floret and $s b 1$ has fewer influences on fertile floret number. The combined action of $s b 1$ and $s b 2$ changes normal spike into branched spike. Furthermore, the duration of the days to maturate and all the investigated spike characters in this new spike changed greatly compared with normal spike. As many genes were involved in development stages and spike characters in wheat, more research should be deeply conducted on the roles of $s b 1$ and $s b 2$ in this new kind of spike

\section{Acknowledgements}

This research was supported by Major Special Program in New Cultivar Breeding (2009CB118300) and 
(2009ZX08002-017B). Many thanks to the graduated and in-reading students from Agronomy College, Shandong Agricultural University taking part in much work in the fields. Great thanks also to wheat breeder Professor Shao Zixing in Agricultural Science College of Taian, who kindly provided the original wheat materials in this research.

\section{References}

Aliyeva, J. A., \& Aminov, K. N. (2011). Inheritance of the branching in hybrid populations among tetraploid wheat species and the new branched spike line 166-Schakheli. Genet Resour Crop Evol, 58, 621-628. http://dx.doi.org/10.1007/s10722-011-9702-9

Biesaga-Koscielniak, J., Koscielniak, J., Filek, M., Marcinska, I., Krekule, J., Machackova, I., \& Kubon, M. (2010). The effect of plant growth regulators and their interaction with electric current on winter wheat development. Acta Physiologiae Plantarum, 32(5), 987-995. http://dx.doi.org/10.1007/s11738-010-0488-8

Chen, Y., Brett, F. C., Wang, S. W., Cao, S. H., \& Yan, L. L. (2010). Genetic regulation of developmental phases in winter wheat. Mol Breeding, 26, 573-582. http://dx.doi.org/10.1007/s11032-010-9392-6

Coffman, F. A. (1924). Supernumerary spikelets in Mindum wheat. Journal of Heredity, 15, 187-192. http://dx.doi.org/10.1007/s11032-010-9392-6

Danilevskaya, N. O., Meng, X., \& Evgueni, V. A. (2010). Concerted Modification of Flowering Time and Inflorescence Architecture by Ectopic Expression of TFL1-Like Genes in Maize. Plant Physiology, 153, 238-251. http://dx.doi.org/10.1104/pp.110.154211

Dencic, S. (1988). Genetic analysis of different structures of sink capacity in wheat. In Proc. 7th Intern. Wheat Genet. Symp., Cambridge, UK. pp. 499-502.

Flood, R. G., \& Halloran, G. M. (1984). Basic development rate in spring wheat. Agronomic Journal, 76, 260-264.

Gbmez-Macpherson, H., \& Richards, R. A. (1997). Effect of early sowing on development in wheat isolines differing in vernalisation and photoperiod requirements. Field Crops Research, 54, 91-107. http://dx.doi.org/10.1016/S0378-4290(97)00057-9

Gonzalez, F. G., Slafer, G. A., \& Miralles, D. J. (2005). Pre-anthesis development and number of fertile florets in wheat as affected by photoperiod sensitivity genes Ppd-D1 and Ppd-B1. Euphytica, 146, 253-269. http://dx.doi.org/10.1007/s10681-005-9021-3

Huang, G., \& Yen, C. (1988). Studies on the developmental genetics of multiple spikelet per spike in wheat. In: Proc. 7th Intern. Wheat Genet. Symp., Cambridge, UK, pp. 527-532.

Koric, S. (1969). Utilization of branched genic complex for increasing for productivity of Triticum aestivum ssp. vulgare. Savrem Poljopr, 17, 151-158.

Koric, S. (1975). Genetic basis for high spike productivity, In Proceedings of the $2^{\text {nd }}$ International Winter wheat Conference, 188-144.

Koric, S. (1980). Study of branched gene complex of Triticum aestivum ssp. vulgare and its significance for wheat breeding. J Sci Agric Res Zagreb Yugoslavia, 142, 271-282.

Lewis, S., Faricelli, M. E., Appendino, M. L., Valárik, M., \& Dubcovsky, J. (2008) The chromosome region including the earliness per se locus Eps-Aml affects the duration of early developmental phases and spikelet number in diploid wheat. Journal of Experimental Botany, 59(13), 3595-3607. http://dx.doi.org/10.1093/jxb/ern209

Li, W. P., \& Zhao, W. M. (2000) A breeding method for increasing spikelet and studies on creation of new germplasm resource in wheat. Acta Agron Sin, 26, 222-230.

Oscarson, P., Lundborg, T., Larsson, M., \& Larsson, C. M. (1995). Fate and effects on yield components of extra applications of nitrogen on spring wheat (Triticum aestivum L.) grown in solution culture. Plant and Soil, 175(2), 179-188. http://dx.doi.org/10.1007/BF00011353

Peanell, A. L., \& Halloran, G. M. (1983). Inheritance of supernumerary spikelet development in wheat. Euphytca, 32, 767-776.

Peng, Z. S., Yang, J. L., Wei, S. H., \& Zeng, J. H. (2004). Characterization of the common wheat (Triticum aestivum L.) mutation line producing three pistils in a floret. Hereditas, 141, 15-18. http://dx.doi.org/10.1111/j.1601-5223.2004.01787.x 
Samsampour, D., Zanjani, B. M., Pallavi, J. K., Singh, A., \& Charpe, A. (2010). Identification of molecular markers linked to adult plant leaf rust resistance gene $\operatorname{Lr} 48$ in wheat and detection of $L r 48$ in the Thatcher $\begin{array}{lllll}\text { near-isogenic line with gene Lr25. Euphytica, 174(3), 337-342. } & \text {. }\end{array}$ http://dx.doi.org/10.1007/s10681-009-0114-2

Seversike, M. T., Ray, D. J., Shultz, L. J., \& Purcell, C. L. (2008). Soybean molecular linkage group B1 corresponds to classical linkage group 16 based on map location of the If 2 gene. Theoretical and Applied Genetics, 117(2), 143-147. http://dx.doi.org/10.1007/s00122-008-0759-6

Sharman, B. C. (1967). Interpretation of the morphology of various naturally occurring abnormalities of the influorescence of wheat (Triticum ssp.). Canadian Journal of Botany, 45, 2073-2080. http://dx.doi.org/10.1139/b67-224

Sun, D. F., Zhu, X. D., Wan, Z. B., \& Cai, J. (2000). The stability and expression in $F_{1}$ generation of supernumerary spikelets in bread wheat. Journal of Huazhong Agricultural University, 19, 213-218.

Tschermak, von E. (1914). Uber die Vererbungsweise von Art und Gattungsbastarde innerhalb der Getreidegruppe. Mitteil. Der landw. Lehrkanzeln der KK Hochschule für Bodenkultur in Wien Bd. (ii) Heft.

Verhulst, N., Govaerts, B., Nelissen, V., Sayre, K. D., Crossa, J., \& Raes, D. (2011). The effect of tillage, crop rotation and residue management on maize and wheat growth and development evaluated with an optical sensor. Field Crops Research, 120(1), 58-67. http://dx.doi.org/10.1016/j.fcr.2010.08.012

Waddington, S. R., Cartwright, P.M., \& Wall, P.C. (1983). A quantitative scale of spike initial and pistil development in barley and wheat. Annals of Botany, 51, 119-130.

Yan, X. H. (2007). Chromosome mapping of branched spike gene and gene cloning of ramosa 2 in wheat. Thesis for Masters Degree. Northwest Agricultural and Forestry University. YangLing, Xian City, China. 25-32.

Yan, L., Fu, D., Li, C., Blechl, A., Tranquilli, G., Bonafede, M., Sanchez, A., Valarik, M., Yasuda, S., \& Dubcovsky, J. (2006). The wheat and barley vernalization gene VRN3 is an orthologue of FT. Prod Natl Acad Sci USA, 103, 19581-19586. http://dx.doi.org/10.1073/pnas.0607142103

Yan, L., Loukoianov, A., Tranquilli, G., Blechl, A., Khan, I. A., Ramakrishna, W., SanMiguel, P., Bennetzen, J. L., Echenique, V., Lijavetzky, D., \& Dubcovsky, J. (2004). The wheat VRN2 gene is a flowering repressor down-regulated by vernalization. Science, 303, 1640-1644. http://dx.doi.org/ 10.1126/science.1094305

Yan, L., Loukoianov, A., Tranquilli, G., Helguera, M., Fahima, T., \& Dubcovsky, J. (2003) Positional cloning of wheat vernalization gene VRN1. Proc Natl Acad Sci USA, 100, 6263-6268. http://dx.doi.org/10.1073/pnas.0937399100

Yan, M. L., Liu, Z. S., Guan, C. Y., Chen, S. Y., \& Yuan, M. Z. (2009). Inheritance and molecular markers for the seed coat color in Brassica juncea. Frontiers of Agriculture in China, 3(1), 1-6. http://dx.doi.org/10.1007/s11703-009-0019-9

Yuan, W. Y., Sun, Y., Chang, M. R., Pei, Z. Y., \& Sun, S. C. (1995). Genetics study on common wheat with branched spike transferred from Triticum turgidum Compositum. Acta Agriculturae Boreali-Sinica, 10(3), 45-50.

Zadoks, J. C., Chang, T. T., \& Konzak, C. F. (1974). A decimal code for the growth stage of cereals. Weed Research, 14, 415-421.

Zhang, J., Liu, W. L., Yang, X. M., Gao, A. N. Li, X., Wu, X. Q., \& Li, X. (2011). Isolation and characterization of two putative cytokinin oxidase genes related to grain number per spike phenotype in wheat. Molecular Biology Reports, 38(4), 2337-2347. http://dx.doi.org/10.1007/s11033-010-0367-9

Zhao, P., Peng, H. R., Ni, Z. F., Lu, L. H., Wang, J., \& Sun, Q. X. (2009). Heterosis and combining ability of major agronomic traits in crosses between ear-branched wheat and common wheat. Journal of Triticeae Crops, 29(2), 212-216. 